\title{
Preface to Three Masonic Comedies
}

In this book I have translated three plays inspired by the early and mid-18th century spread of freemasonry from the British Isles to continental Europe and beyond. To set them in context and to open up their themes I have also included an extended introductory essay. This is very much the work of a classicist let loose in the early modern world and this will be apparent from my particular interest in how the plays interact with cultural and literary models from antiquity. At the close of the introduction I also show how the relationship between masonic life and drama can offer an enlightening comparison for some much-debated phenomena in ancient dramas centred on the mysteries.

It has been a delight to get to grips with works in French, German, and Italian as well in the classical languages with which I am most at home. Yet to make my ideas accessible to as many anglophone readers as possible, I have translated not only the plays themselves but all other quotations included in the introduction. The only exception to this is in the titles of the plays and of the various masonic books and pamphlets that I cite. For the latter I have devised my own abbreviations and have included a full list of these at the front of the volume.

The immediate inspiration for this study came from Fiona Macintosh and Marina Warner, who invited me to contribute a paper on Goldoni to a conference on Classcial Reception in Italy organised by the Archive for the Performance of Greek and Roman Drama in Oxford in May 2016. I knew something about ancient comedy, curiosity, and Goldoni, and recalled that my colleague at the University of Trento, Gabriella Moretti, had previously suggested that I read Goldoni's Le Donne Curiose. And so it all started.

Of freemasonry I knew next to nothing. What I have learned since then is down to the wonderful collections of the Weston Library in Oxford and, in particular, the library and museum of the United Grand Lodge of England in London. Martin Cherry, Susan Snell, and their team have been unfailingly generous in their support, and Peter Aitkenhead has offered extraordinarily swift and detailed responses to queries on a range of topics. I have also gained much assistance from the libraries of the Taylorian Institute in Oxford, Wadham College, Oxford, and the Wellcome Institute in London.

Various friends have guided me along the way. Alice Wright was an early supporter of this project. Ela Tandello and Andrea Bocchi advised on tricky passages in Griselini and Richard Cooper on similar problems in Clément. Andrew Prescott read and corrected my introduction. Robert Parker read a first draft of my account of ancient mystery cults and suggested much recent scholarship that otherwise I would have missed. Francesca Romana Berno supplied photocopies 
of texts I was struggling to run to ground. Catherine Keen was consistently encouraging and supportive. Audiences at Oxford, Warwick, UCL, the United Grand Lodge of England, and the University of Texas at Austin listened tolerantly to different parts of my introduction. My students at St Anne's College participated in a read-through of my translation of Le Donne Curiose.

I am particularly grateful to Stephen Harrison, Serena Pirrotta, Anne Hiller, Katerina Zianna, and the team at De Gruyter for their support for a project that, by its very nature, is not easy to fit into many academic publishing series.

At the start of this project I had just got to know Dr Emily Hayes, historian of science and historical geographer, whose intellectual verve and drive both enriched my thoughts and fired my enthusiasm. I am now so very proud to be her husband. 